DOI:10.18535/ijahm/v8i1.04

Impact Factor: 4.415

\title{
An Insight into Relation of Action of Herbs and Srotas
}

\author{
Agrawal Monika ${ }^{1}$,SharmaSaurav ${ }^{2}$, Lal Makhan ${ }^{3}$ \\ ${ }^{1}$ PG Scholar, Dept. of Dravyaguna, Rajkiya Ayurvedic College, Tudiyaganj, Lucknow, U.P., India \\ ${ }^{2}$ Professor \& Head, Dept. of Dravyaguna, Rajkiya Ayurvedic College, Tudiyaganj, Lucknow, U.P., India \\ Corresponding author: Monika Agrawal \\ Address: Dravyaguna department, Rajkiya Ayurveda Mahavidyalaya evam Chikitsalya, Tudiyaganj, \\ Lucknow.
}

\begin{abstract}
The word srotas is derived from "sru"gataudhatu which means movement.Srotas are channels which transport anna, dhatus, tridoshas and pranas. When the flow of appropriate nutrients through srotas is proper and unobstructed, there is health. When there is blockage, excess or deficiency in these channels, disease occurs. Herbs act in various ways. Some stop attipravitti while others removesang. In this article an effort has been made to analyze the action of dravyas in different pathologies exclusively at srotas level in order to highlight their medico clinical importance in our body.
\end{abstract}

Key words: Srotas, Herbs, Channels, Ayurveda.

\section{Introduction}

Acharya Charak has stated "Tadetat srotsam prakatibhutatwat na vikarairoopsrijyate shariram" i.e.samprapti (pathogenesis) of any disease involves the srotodushti in its progression[1]. No disease can occur without srotodushti. Hence a thorough knowledge of srotas present in human body is the basic necessity to understand the action of Ayurvedic medicines. That may be the reason,Acharya Charakhas mentioned this important topic in Vimana sthana, where the 'vishisht maan'of the body has been described[1]. Similarly Acharya Shusruta gave importance to this topic by dedicating a separate chapter on srotasin Shareer sthana[2]. To be noticed, Acharya Charakhas used the termsrotas directly and indirectly while describingsamprapti of maximum diseases e.g.

Sleshmada rudha marg tat - Shakhashrita Kamala (C.Chi.16/1225)

Srotansya adhisthay manovahani - Unmada (C.Chi.9/5)

Dosha prakupita sthanm adhigamya - Kustha (C.Ni.5/6)

Rakten aavrita pathi - Vatarakta (C.Chi.29/10) etc.

Dosha-dushya sammurchana occurs in srotas, duringsthan- sanshraya avastha of samprapti.Ayurvedic system of diagnosis is based as on which of the individual dosha are involved \& which channels are obstructed or afflicted. A disease originated from one vitiated dosha can travel through srotas to the site of another dosha. Excess of dushya can either block the srotas or can create a spillover effect. A disease may also involve anatomical problem of srotas or srotomula. The modality of treatment in Ayurveda thus includes the evulsion of obstruction, correction of anomaly or stopping of spillover effect at the nano level of srotasby the use of herbs. Hence the choice of drug in a disease would depend on the type of srotas and anomaly involved.Action of various drugs at srotas level thus highlights the medical importance of srotas in our body. 
Agrawal Monika ${ }^{1}$, International Journal of Ayurvedic \& Herbal Medicine 8(1) Jan.-Feb. 2018 (3079-3083)

\section{Material and Methods}

It is a conceptual research. Ayurvedic texts consulted include Charak Samhita, Sushruta Samhita, Dravyaguna Vigjnan by Late Acharya Priyavrat Sharma, Ras panchak by Dr. S.C. Dhyani etc. Research articles available on internet have also been consulted.

\section{Action of herbs at srotas level of samprampti}

Some herbs act at dosha level, some at dushya while others at srotas level to cure the disease. Many may act at multiple levels e.g.

In Atisaramain dosh involved is - vata

main dushya involved is - purish

main srotas involvedis - Purishvah(mainly pakvashya).

Shunthichiefly acts on Vata, Bhangaon purish while Ahifenon purishvaha srotas. It is quite common to use poppy for Atisara when all measures fail. Being Ruksha \& kashaya it is sthambhak, hence, decreases excess secretion by purishvaha srotas. At the same time causes decreased intestinal motility by being Vata shamak because of ushna virya. Morphine present in Ahifen reduces GIT motility thus helps in diarrhea as reported by Casy et al., 1986[3].

\section{Action of herbs on sroto dushti (sanga\&atipraviti)}

The cardinal symptoms of disease relates, in high majority of cases, to the hypofunctioning ( sang) or hyper functioning (atipraviti) of the srotamsi involved in it and the vyadhi pratyneekachikitsa aims at correcting these defects e.g. Svasaand Kaas roga occur due to sanga in praanvaha srotas. The sanga may be due to the spasm (Vayu) or kapha. Medicines acting on vata\& kapha as well as praanvaha srotasare therefore used in theserogas.

Kustha (Saussurea lappa) by its ushna virya \&katu- tikta rasa rectifies vata\&kaphathus removes the sanga of praanvaha srotas, which in modern paralance is bronchodilating and spasmolytic action (Raghvan et al., 1962)[4].

Taalish patra, Tulsi and Twak through their oil content liquefies kapha which is then easily expectorated, thus by removing sanga of praanvahasrotashelp in svasa.

Vasa removes the sanga of praanvaha srotas by being expectorant and bronchodilator.

Vibhitak corrects the hyperactivity of praanvaha srotas by being kaph shamak and antitussive.

Ela exhibits bronchodilatory effect, mediated through $\mathrm{Ca}$ ion antagonist mechanism, hence improves hyperactive status of respiratory system[5].

Raktastambhak drugs like Lodhra, Doorva, Shatavari, Vasa, Kushmandetc. owing to their sheet \& kashaya properties enhances the coagulation process and constrict the rakt vahidhamniya, the moola of raktvahi srotas, thus are used in Raktpitta (attipravitti)[6].

Ashok twakis used in raktapradar, a disease of aartavvahi srotas. Ashok twak acts on Garbhasaya (uterus), the mula of aartavvahi srotas, induces its contraction thus regulates menstrual bleeding[7].

\section{Elective affinity of herbs towards srotas}

Certain herbs exhibit selective affinity toward a particular srotas. Lodhra, Naagkesar\&Mochrasare well established Raktasthambhak dravyas. But when it comes to choice of medicine for Raktarsh we choose Naagkesar, for rakpradar Lodhra\& for raktaatisara Mochras is our choice (table 1), though all the three diseases involve common dosha \& dushya. It is the type of srotas involved \& the elective affinity of herbstowards it which makes the difference. 
Agrawal Monika ${ }^{1}$, International Journal of Ayurvedic \& Herbal Medicine 8(1) Jan.-Feb. 2018 (3079-3083)

Table: 1

\begin{tabular}{|c|c|c|c|c|}
\hline Disease & Pradhan Dosh & Pradhan Dushya & Srotas & Dravya \\
\hline Raktarsh & Pitta & Rakta & Maansvaha & Naagkesar \\
\hline Raktapradar & Pitta & Rakta & Aratavvaha & Lodhra \\
\hline Raktaatisara & Pitta & Rakta & Purishvaha & Mochras \\
\hline
\end{tabular}

\section{Remote action of herbs \&srotas}

Dosha, dhatu, mala \& srotas mutually affect each other. Medicines after absorbtion through ras-rakta circulation reach to their site of action \& cure the pathology which may affect other related organ or avayav. This is called Remote action of dravya. This is utilized when a remote situated sroto dushti is the culprit of another problem e.g. Arogyavardhani removes the sanga (obstruction) of liver thus also resolves related Ascites.

Punarnava is metioned in kasahara mahakashaya by Charaka[8].Though it doesn't have any direct effect on lungs but due to its diuretic action reduces the congestion (sanga) in the lungs which gives symptomatic relief in congestive conditions of lung tissues.

\section{Action of herbs at srotomula}

"Chinnamula na shakha na pattram"[9]

Whether be dos has or plants, if the roots are not attacked upon, reappearance of the gone away disease and sprouts respectively is obvious[10]. Hence treatment of srotomula is very important.

Mukhdhusika is a raktavaha srotodushti janit vikara. The moola of raktavaha srotas are Yakrit \&Plihaand raktvaahi dhamniya[11, 12].So if we treat yakrit \& pliha we can cure Mukhdushika. Rohitaka\&Sharpunkha can be used as a remedy as both have stimulating property of yakrit and pliha. Rohitaka, due to predominance of tikta \& kashaya ras alleviates pitta whiledue to ushna virya it alleviates kapha \& vata, thus due to these properties it is plihanga \& raktasodhaka dravya.

Sharpunkha due to laghu, ruksha guna \& tikt-kashaya rasaalleviates kapha \& pitta and due to sheet virya exhibits plihanga \& raktashodhak effects. In modern aspect, spleen acts as reticulo-endothelial system and liver detoxifies waste products of blood (Chowdhury et al; 2013) [13].

Classification of drugs as per their action on srotas[14]

Table: 2

\begin{tabular}{|l|l|}
\hline Praanvaha srotas & $\begin{array}{l}\text { Vibhitaka, Yashtimadhu, Vasa, Taalish patra, Gojheeva, Pushkarmoola, Kantkari, } \\
\text { Twak, Kusth, Tulsi etc. }\end{array}$ \\
\hline Udakvaha srotas & Chandan, Usheer, Dhaanyak, Kiratikta etc. \\
\hline Annavaha srotas & $\begin{array}{l}\text { Chitrak, Pippali, Sunthi, Jeerak, Methika, Suvarchala, Shatpushpa, Nimbu, Amlika } \\
\text { etc. }\end{array}$ \\
\hline Rasvaha srotas & $\begin{array}{l}\text { Arjun, Amlaki, Guduchi, Paatla, Moorva, Sudarshan, Nirgundi,, Agnimantha, } \\
\text { Jeevanti, Shatavari, Ashwagandha etc. }\end{array}$ \\
\hline Raktavaha srotas & $\begin{array}{l}\text { Manjistha, Haridra, Bakuchi, Padmak, Chakramarda, Laaksha, Nimb, Karanja, } \\
\text { Sharpunkha, Doorva, Kumari, Rohitak etc }\end{array}$ \\
\hline Maansavaha srotas & Lashun, Bhallataka, Chavya, Panas, Aguru, Madhook etc. \\
\hline Medovaha srotas & Karpur, Guggulu, Paaribhadra, Apamaarg, Kaanchnaar etc. \\
\hline Asthivaha srotas & Asthisrinkhla, Bakul, Chadak etc. \\
\hline Majjavaha srotas & Chopcheeni, Hapusha, Dhamasa, Shalmali etc. \\
\hline Shukravaha srotas & Kasturi, Kapikacchu, Akshot, Paataalgaruni etc. \\
\hline
\end{tabular}


Agrawal Monika ${ }^{1}$, International Journal of Ayurvedic \& Herbal Medicine 8(1) Jan.-Feb. 2018 (3079-3083)

\begin{tabular}{|l|l|}
\hline Mutravaha srotas & Pashanbheda, Yavakshar, Gokshru, Kush, Kulatha, Kaarvellaka etc. \\
\hline Purishavaha srotas & Haritaki, Jaatiphala, Bilva, Mochrasa, Kapitha etc. \\
\hline Swedavaha srotas & Vatsnaabh, Shobhaanjan, Naagkesar, Priyangu etc. \\
\hline Artavavaha srotas & Lodhra, Gorochana, Saariva, Lajjalu, Ashok, Plaksha etc. \\
\hline
\end{tabular}

\section{Discussion}

On the basis of above study, it can be said that every Ayurvedic drug should be researched or studied on the basis of mode \& site of action with respect to srotas invloved. In routine Ayurvedic practice, it is observed that a drug which acts wonderfully in patient of one disease may not show any beneficial effect in another patient with similar disease. In my opinion the reason behind it on detailed study can be understood taking an example of Ascites. The common causes of Ascites are Liver cirrhosis, Renal failure, Cox abdomen, CHF and Carcinoma[15]. Arogyavardhini which works wonderfully in Ascites due to Cirrhosis will be useless in Ascites due to Cox abdomen, CHF, RF etc. As the main content Katuki (Picchrorhiza kurroa) acts on srotodushti of liver which is the main culprit. Similarly, Trinpanchmool dravyas are very effective in Ascites due to renal pathology but play negligible role in other causes.

\section{Conclusion}

From this study we conclude that

1. Srotas are involved in pathogenesis of diseases.

2. Dravyas used for treatment of disease act at srotas through various mechanism.

3. A physician must observe the clinical manifestations of disease to trace out the srotas involved so as to make choice of medicine.

4. Further work is still much needed in this field.

\section{References}

1. Agnivesh, Charak, Charak samhita, Vimaan sthana, Srotoviman Adhyaya, Chapter 5, Shlok 6, edited by Ganga Sahay Pandey, Vidyotini Hindi commentary by Shastri K. N and Chaturvedi G. N., part 1, Chaukhamba Sanskrit sansthan, Varanasi, Reprint year 2001.

2. Sushruta, Sushruta Samhita, Shareer Sthana Dhamnivyakrana, Chapter 9, Shlok 12,13. Edited by Prof. Kaviraj Ambikadatt shastri. Chaukhamba Sanskrit sansthan, Varanasi, Second Edition, Reprint year : 2005.

3. Casy AF, Parfitt RT. Opoid analgesics. Springer; 1986.

4. Raghvan P, Nagendra AS, Dutta NK. Total alkaloids of Saussurea lappa in treatment of bronchial asthma. An assessment of its therapeutic value by clinical \& ventilator function studies. J Postgrad Med 1962; 8:158-169.

5. Arif- ullah Khan 1, 2, Qaiser Jabeen Khan 1,3 and Anwarul- Hassan Gilani 1; Pharmacological basis for the medicinal use of Cardamom in asthma; Bangladesh J Pharma 2011; 6: 34-37.

6. Basic concepts of Dravyaguna Vijnana by Dr. Anugrah Narain Singh and Prof. Satya Deo Dubey, Chaukhambha Vishvabharti, Varanasi, $1^{\text {st }}$ edition 2014.

7. Dravyaguna Vijnana by Prof. P. V. Sharma, Chaukhambha Bharti Academy, Varanasi, Reprint year 2011,pg 618 .

8. Agnivesh, Charak, Charak Samhita, Sutrasthan, Shadvirechanshtashati adhyay Chapter 4, Shlok 36, edited by Ganga Sahay Pandey, Vidyotini Hindi commentary by Shastri K. N and Chaturvedi G. N. , part 1, Chaukhamba Sanskrit sansthan, Reprint year 2001, Varanasi.

9. Bhagvat Geeta

10. Agnivesh, Charak, Charak Samhita, Sutrasthan,Chikitsaprabhrityamadhyay, Chapter 16, Shlok 21, edited by Ganga Sahay Pandey, Vidyotini Hindi commentary by Shastri K. N and Chaturvedi G. N. , part 1, Choukhamba Sanskrit sansthan, Reprint year 2001, Varanasi. 
Agrawal Monika ${ }^{1}$, International Journal of Ayurvedic \& Herbal Medicine 8(1) Jan.-Feb. 2018 (3079-3083)

11. Agnivesh, Charak, Charak Samhita, Vimansthan,Srotoviman Adhyaya, Chapter5, Shlok7, edited by Ganga Sahay Pandey, Vidyotini Hindi commentary by Shastri K. N and Chaturvedi G. N. , part 1, Choukhamba Sanskrit sansthan, Reprint year 2001, Varanasi.

12. Sushruta, Sushruta Samhita, Shareer Sthana Dhamnivyakrana, Chapter 9, Shlok 12. Edited by Prof. Kaviraj Ambikadatt shastri. Chaukhamba Sanskrit sansthan, Varanasi, Second Edition, Reprint year : 2005.

13. Chowdhury Kanchan, Dhakar Rajkumar, Patil Bansilal Satish, Jain Rahul, Datta Nilanjan. Role of Rohitaka and Sharpunkha on Mukhadushika. International Journal Of Ayurvedic And Herbal Medicine, 3;3 (2013)1159: 1172.

14. Dhyani S C, Rasa-Panchaka, Varanasi, Chowkhamba Krishnadas Academy; Edition $4^{\text {th }}, 2016$, pg $134-$ 135.

15. Davidson's Principles \& Practice of Medicine. Edition $20^{\text {th }} \cdot \mathrm{pg} 937$. 